\title{
PENGARUH KECERDASAN SPIRITUAL TERHADAP KINERJA KARYAWAN BIRO QUALITY ASSURANCE PT. SEMEN PADANG
}

\author{
Nurul Annisa, Riri Mayliza \\ Sekolah Tinggi Ilmu Ekonomi "KBP" \\ ririmayliza@akbpstie.ac.id
}

\begin{abstract}
In an effort to build a company that has a high employee performance today requires a comprehensive intelligence for human resources who manage the company. All human resources managing the company must perform well. Performance is good without any intelligence then it means nothing. In this study the intent of intelligence is spiritual intelligence that affects the performance of employees. Employee performance described in the dependent variable and spiritual intelligence is the independent variable. In the indicator of spiritual intelligence variables explain as follows; 1. Honest 2. Openness 3. Self-knowledge 4. Focus on contribution 5. Spiritual non-dragmati. While for employee performance variable indicator is 1. Quality 2. Quantitras 3. Timeliness 5. Independence. In the results of research and discussion of which the value of f test is 0.001 This indicates that the influence of spiritual intelligence together on the performance of employees. As for the t test shows the value of $0.001<0.05$ of the value can be explained that spiritual intelligence significantly affects employee performance.
\end{abstract}

Keywords: spiritual intelligence and performance

\section{PENDAHULUAN}

Setiap perusahaan harus mampu mengatur dan mengolah semua sumber daya yang dimilikinya dengan efektif dan efisien agar tetap dapat bertahan hidup dan berkembang. Salah satu contoh dari sumber daya perusahaan tersebut adalah sumber daya manusia (tenaga kerja atau karyawan).

Sumber daya manusia mempunyai peran utama dalam setiap kegiatan perusahaan, walaupun didukung dengan sarana dam prasarana serta sumber dana yang berlebihan, tetapi tanpa adanya dukungan sumber daya manusia yang andal kegiatan perusahaan tidak akan berjalan dengan baik. Hal ini membuktikan bahwa sumber daya manusia merupakan kunci pokok yang harus diperhatikan dengan segala kebutuhannya. Sebagai kunci pokok, sumber daya manusia akan menentukan keberhasilan pelaksanaan kegiatan perusahaan.

Adapun yang harus kita ketahui bahwa, manajemen diciptakan dengan tujuan mengatur alokasi (allocation) dan penggunaan (utilization) sumber daya perusahaan baik (tangible maupun intangible asset) untuk mencapai tujuan organisasi/perusahaan secara efektif dan efisien. Pakar-pakar terdahulu jarang 
sekali mengangkat unsur spiritual dalam mengkaji dan merumuskan teori-teori dan strategi-strategi manajemen. Namun perkembangan zaman ini telah membuka mata para ahli manajemen bahwa unsur spiritual juga mempunyai peran yang sangat penting dalam membangun berbagai fungsional manajemen, seperti dalam Manajemen Sumber Daya Manusia (MSDM).

Dalam usaha membangun suatu perusahaan yang memiliki performasi karyawan yang tinggi saat ini dibutuhkan suatu kecerdasan yang menyeluruh bagi SDM yang mengelola perusahaan tersebut. Sampai saat ini, para pakar tentang kecerdasan menggolongkan tiga jenis kecerdasan yaitu: kecerdasan intelektual (IQ), kecerdasan emosional (EQ), dan kecerdasan spiritual (SQ).

Fenomena yang terlihat di lapangan bahwa SDM perusahaan pada umumnya dan PT Semen Padang khususnya dalam perekrutan karyawan baru lebih memprioritaskan pada kecerdasan intelektual (IQ), dibandingkan dengan kecerdasan emosional (EQ) dan kecerdasan spiritual (SQ). Dapat kita lihat dari segi perekrutan karyawan yang mayoritas diterima oleh perusahaan adalah kebanyakan orang-orang pilihan yang berotak cerdas dari segi intelektual (IQ).

Berdasarkan latar belakang tersebut di atas, masalah dalam penelitian ini dirumuskan sebagai berikut: 1. Apakah kecerdasan spiritual berpengaruh terhadap kinerja karyawan pada Biro Quality Assurance PT Semen Padang.

\section{KAJIAN TEORI}

\section{Kinerja}

Kinerja sumber daya manusia merupakan istilah yang berasal dari kata Job Performance atau Actual Performance yaitu prestasi kerja atau prestasi sesungguhnya yang dicapai oleh seseorang Mangkunegara (2010). Definisi kinerja sumber daya manusia dinyatakan oleh beberapa ahli, diantaranya: " perilaku nyata yang ditampilkan setiap orang sebagai prestasi kerja yang dihasilkan oleh karyawan sesuai dengan perannya dalam perusahaan Rivai (2005) " mengatakan bahwa pengertian kinerja adalah penampilan, hasil karya personil baik kualitas, maupun kuantitas penampilan individu maupun kelompok kerja personil, penampilan hasil karya tidak terbatas kepada personil yang memangku jabatan fungsional maupun struktural tetapi juga kepada keseluruhan jajaran personil di dalam organisasi llyas (2005), "hasil kerja baik yang kuantitas maupun kualitas yang dicapai oleh seseorang dalam melaksanakan tugas sesuai tanggung jawab yang diberikan" Mangkunegara (2009), "konsep yang bersifat universal yang merupakan efektivitas operasional suatu organisasi, bagian organisasi dan bagian karya berdasarkan standar perilaku yang ditetapkan untuk mencapai hasil yang diinginkan" Siagian (2003).

2. Kecerdasan Spiritual

Zohar dan Marshall (2001) mendefinisikan kecerdasan spiritual sebagai rasa moral, kemampuan menyesuaikan aturan yang kaku dibarengi dengan pemahaman dan cinta serta kemampuan untuk melihat kapan cinta dan pemahaman sampai pada batasannya, juga memungkinkan bergulat dengan ihwal baik dan jahat, membayangkan yang belum terjadi serta mengangkat dari kerendahan. Kecerdasan spiritual adalah kecerdasan untuk menghadapi dan memecahkan persoalan makna dan nilai, yaitu menempatkan perilaku dan hidup manusia dalam konteks makna yang lebih luas dan kaya, serta menilai bahwa tindakan atau jalan hidup seseorang lebih bermakna dibandingkan dengan orang lain. 
Eckersley (2000; dalam Trihandini, 2005) mendefinisikan kecerdasan spiritual sebagai perasaan instuisi yang dalam terhadap keterhubungan dengan dunia luas di dalam hidup manusia. Agustian (2006) mendefinisikan kecerdasan spiritual adalah kemampuan memberi makna ibadah terhadap setiap perilaku dan kegiatan melalui langkah-langkah dan pemikiran yang bersifat fitrah, menuju manusia yang seutuhnya dan memiliki pola pemikiran integralistik serta berprinsip hanya karena Allah.

3. Kerangka Konseptual

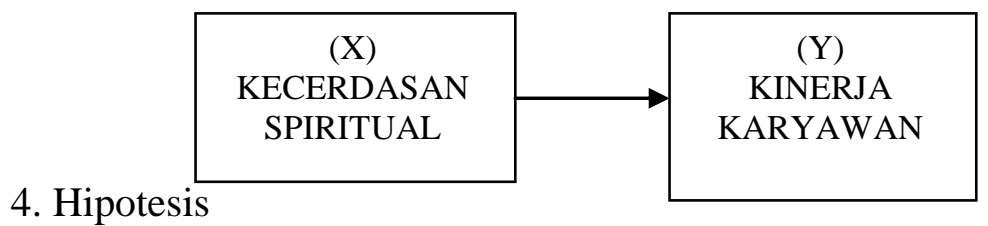

Berdasarkan rumusan masalah yang telah dikemukakan, maka dapat dirumuskan hipotesis sebagai berikut: H1 :Diduga kecerdasan spiritual berpengaruh terhadap kinerja karyawan pada Biro Quality Assurance PT Semen Padang.

\section{METODE PENELITIAN}

\section{Jenis Penelitian}

Jenis penelitian yang digunakan dalam penelitian ini adalah penelitian kuantitatif. Menurut Sugiyono (2014) penelitian kuantitatif digunakan untuk meneliti pada populasi atau sampel tertentu.Teknik pengambilan sampel umumnya dilakukan secara random, pengumpulan data mengunakan instrumen penelitian, analisis data bersifat kuantitatif / statistik dengan tujuan untuk menguji hipotesis yang ditetapkan.

2. Populasi dan Sampel

Populasi merupakan sekumpulan objek yang ditentukan melalui suatu kriteria tertentu yang akan dikategorikan ke dalam objek tersebut bisa termasuk orang, dokumen atau catatan yang dipandang sebagai objek penelitian. Populasi menurut Sugiyono (2014) adalah wilayah generalisasi yang terdiri atas objek atau subjek yang mempunyai kualitas dan karakteristik tertentu yang ditetapkan oleh peneliti untuk dipelajari dan kemudian ditarik kesimpulannya. Populasi dalam penelitian ini adalah seluruh karyawan pada biro Quality Assurance.

Menurut Sugiyono (2004:73), sampel adalah bagian dari jumlah dan karakteristik yang dimiliki oleh populasi tersebut. Teknik pengambilan sampel pada penelitian adalah total sampling (Sugiyono,2007) total sampling adalah teknik pengambilan sampel dimana jumlah populasi sama dengan jumlah sampel. Alas an mengambil teknik total sampling karena jumlah populasi yang kurang dari 100 dan seluruh populasi dijadikan sampel penelitian yang berjumlah 35 orang

\section{ANALISA DAN PEMBAHASAN}

1. Gambaran Umum Responden

Dalam penelitian ini penulis memberikan gambaran responden pada biro quality assurance pada PT. Semen Padang. Yang memjadi responden adalah karyawa-karyawan yang bekerja di biro quality assurance yang terdiri dari 35 orang. Untuk itu peneliti menyebar kuesioner sebanyak 35 buah akan tetapi dari 
35 buah tersebut yang dapat diolah hanya 30 kuesioner, dan 5 kuesioner tidak dapat diolah dikarenakan kondisi kuesioner tidak diisi secara lengkap.

2. Demografi Responden

Sebelum melakukan penelitian penulis ingin memberikan demografi responden yang telah mengisi kuesioner yang disebarkan penulis di Biro Quality Assurance PT. Semen Padang. Demografi yang akan dijelaskan adalah sebagai berikut: Dari 30 responden, sebanyak 18 orang atau $60,0 \%$ berjenis kelamin lakilaki, sedangkan selebihnya yaitu sebanyak 12 orang atau 40,0\% berjenis kelamin perempuan. Dari hasil tersebut dapat disimpulkan bahwa jumlah karyawan di Biro Quality Assurance yang menjadi sampel penelitian ini mayoritas berjenis kelamin laki-laki. Dengan melihat tabel di atas dapat diketahui bahwa dari 30 responden yang diteliti terdapat 14 atau 46,7\% responden berumur 31-35 tahun, sedangkan responden yang berumur 20-25 tahun hanya 1 atau 3,3\% responden, untuk umur 26-30 sebanyak 9 atau 30,0\% sedangakan untuk umur 36-40 tahun sebanyak 6 responden atau 20,0\% Melihat hal ini peneliti menyimpulkan bahwa umur yang dominan di biro quality assurance adalah yang berumur 31-35 tahun.

Berdasarkan tabel 4.3 diperoleh data bahwa yang berpendidikan di biro quality assurance terbanyak adalah S1 dengan jumlah responden 17 atau 56,7\%. Untuk pendidikan SMA sebanyak 3 atau $10,0 \%$ responden dan untuk pendidikan D3 sebanyak 10 atau $33,3 \%$ responden.

\section{HASIL PENELITIAN}

1. Uji Normalitas

Tujuan dari uji normalitas risidual adalah untuk menguji dalam sebuah model regresi, variabel dependen dan variabel independen terdistribusi secara normal atau tidak. Pengujian normalitas data dalam penelitian ini dilakukan dengan menggunakan one sample kolmogorov-smirnov test, yang mana jika nilai asymp.sig (2-tailed) $>0.05$ maka distribusi data dikatakan normal. Secara rinci hasil pengujian normalitas dapat dilihat dari tabel 4.10 sebagai berikut: Dari Tabel 4.10, terlihat bahwa nilai asymp.sig (2-tailed) menunjukkan nilai > dari 0.05, yaitu 0.692 Dengan demikian data dapat dikatakan berdistribusi normal.

2. Uji Linieritas

Uji linieritas bertujuan untuk mengetahui apakah kedua variabel mempunyai hubungan yang linier secara signifikan atau tidak. Dengan melihat nilai signifikan $>0,05$ maka variabel tersebut dinyatakan signifikan Secara rinci hasil pengujian normalitas dapat dilihat dari tabel 4.11 sebagai berikut: Berdasarkan tabel 4.11 terlihat pada nilai singnifikan menyatakan $0,056>0,05$ ini berarti bahwa hubungan antara kecerdasan spritiual dengan kinerja karyawan secara signifikan.

3. Uji Heteroskedastisitas

Uji heterokedastisitas dilakukan untuk menguji apakah dalam sebuah model regresi terjadi ketidaksamaan varians dari residual atas suatu pengamatan ke pengamatan lain. Untuk mendeteksi adanya heterokedastisitas pada penelitian ini menggunakan gambar Scatterplots untuk melakukan pengujian. Untuk lebih lengkap lihatlah gambar 4.1 dibawah ini: Berdasarkan output Scatterplots pada gambar 4.1 maka dapat diketahui bahwa; 1.Titik-titik data menyebar diatas dan dibawah atau disekitar angka 0.2. Titik-titik tidak mengumpul hanya diatas atau dibawah saja. 3. Penyebaran Titik data tidak membentuk pola yang jelas. 
Berdasarkan penjelasan diatas maka dapat dinyatakan bahwa uji heteroskedastisitas tidak mempunyai masalah.

4. Uji Regresi Sederhana

Dari persamaan diatas dapat dilihat bahwa terdapat nilai konstanta sebesar 9,525 yang berarti bahwa tanpa adanya kecerdasan spiritual terhadap keputusan pembelian berada pada 3,525 satuan. Nilai koefisien dari variabel X adalah sebesar 0,764 ini berarti bahwa meningkatnya kecerdasan spiritual pada satu satuan, maka akan meningkatkan kinerja karyawan sebesar 0,764.

\section{Uji Hipotesis}

Berdasarkan tabel 4.13 dapat dijelaskan bahwa Nilai $F$ tabel pada $\alpha 0,05$ adalah 4,20. Nilai $F$ hitung adalah 12,893 sedangkan nilai sig adalah 0,001. Dengan demikian berarti $\mathrm{F}$ hitung $>\mathrm{F}$ tabel dan nilai sig $<\alpha 0,05$, yaitu $12,893>$ 4,20 , dan sig $0,001<\alpha 0,05$. Hal ini menunjukkan bahwa model regresi dapat digunakan untuk menguji pengaruh secara bersama-sama variabel independen terhadap variabel dependen, yaitu kecerdasan spritiual terhadap kinerja karyawan.

Untuk mengetahui pengaruh masing-masing variabel maka dilakukan dengan membandingkan nilai $t$ hitung dan $\mathrm{t}$ tabel. Hipotesis diterima jika $\mathrm{t}$ hitung $>\mathrm{t}$ tabel atau nilai $\operatorname{sig}<\alpha 0,05$. Lihat tabel 4.12. Nilai t tabel pada $\alpha=0,05$ adalah 1,7011 . Untuk variabel kecerdasan spiritual nilai t hitung adalah 3,591 atau nilai sig adalah 0,001. Dengan demikian dapat dikatakan bahwa t hitung $>\mathrm{t}$ tabel, yaitu $3,591>1,7011$ atau nilai signifikansi $0,001<\alpha 0,05$. Hal ini menunjukkan bahwa penelitian ini membuktikan kecerdasan spiritual berpengaruh signifikan dan positif terhadap kinerja karyawan sehingga hipotesis ini dapat diterima.

Nilai Adjusted $R$ square menunjukkan 0,291. Hal ini mengindikasikan bahwa kontribusi variabel bebas yaitu kecerdasan spiritual terhadap variabel terikat yaitu kinerja karyawan 0,291, ini dapat diartikan bahwa kecerdasan spritiual ada pengaruhnya dengan kinerja karyawan sebesar $29,1 \%$.

\section{PEMBAHASAN}

Dengan melihat hasil dari Uji $\mathrm{F}$ yang telah dilakukan peneliti maka dapat disimpulkan bahwa pengaruh bersama-sama kecerdasan spiritual terhadap kinerja karyawan berpangaruh signifikan karena nilai $\mathrm{F}$ hitung $<\mathrm{F}$ tabel dan nilai sig $>\alpha$ 0,05 , yaitu $12,893>4,20$, dan sig $0,001<\alpha 0,05$.

Melalui hasil uji $\mathrm{T}$ yang dilakukan peneliti, maka peneliti mengambil kesimpulan bahwa pengaruh kecerdasan spiritual terhadap kinerja karyawan signifikan dan positif karena Nilai t tabel pada $\alpha=0,05$ adalah 1,7011. Untuk variabel kecerdasan spiritual nilai t hitung adalah 3,591 atau nilai sig adalah 0,001. Dengan demikian dapat dikatakan bahwa t hitung $>\mathrm{t}$ tabel, yaitu 3,591 > 1,7011 atau nilai signifikansi $0,001<\alpha 0,05$.

\section{KESIMPULAN DAN SARAN}

\section{Kesimpulan}

Setelah peneliti melakukan penelitian maka peneliti dapat menarik kesimpulan tentang pengaruh kercerdasan spiritual terhadap kinerja karyawan di Biro Quality Assurance pada PT. Semen Padang sebagai berikut: Dengan melihat hasil dari Uji $\mathrm{F}$ yang telah dilakukan peneliti maka dapat disimpulkan bahwa pengaruh bersama-sama kecerdasan spiritual terhadap kinerja karyawan berpangaruh 
signifikan karena nilai $\mathrm{F}$ hitung $<\mathrm{F}$ tabel dan nilai sig $>\alpha 0,05$, yaitu $12,893>$ 4,20 , dan sig $0,001<\alpha 0,05$.

Melalui hasil uji $\mathrm{T}$ yang dilakukan peneliti, maka peneliti mengambil kesimpulan bahwa pengaruh kecerdasan spiritual terhadap kinerja karyawan signifikan dan positif karena Nilai t tabel pada $\alpha=0,05$ adalah 1,7011 . Untuk variabel kecerdasan spiritual nilai t hitung adalah 3,591 atau nilai sig adalah 0,001. Dengan demikian dapat dikatakan bahwa t hitung $>\mathrm{t}$ tabel, yaitu 3,591> 1,7011 atau nilai signifikansi $0,001<\alpha 0,05$.

2. Saran

Berdasarkan hasil penelitian dan kesimpulan maka peneliti memberikan beberapa saran kepada: Dalam melakukan pengukuran kinerja karyawan di Biro Quality Assurance Pada PT. Semen Padang diharapkan tidak hanya mengukur dengan kecerdasan intelektual akan tetapi juga harus mengukur dengan kecerdasan spiritual karena dalam melalui penelitian ini bahwa kecerdasan spiritual berpengaruh juga terhadap kinerja pegawai.

Untuk melakukan penelitian yang berkaitan dengan kinerja karyawan sebaiknya menambahkan atau mencari variabel-variabel lain terhadap kinerja karyawan

\section{DAFTAR PUSTAKA}

Ambar, T. Sulistiyani. Rosidah. 2003. Manajemen Sumber Daya Manusia. Yogyakarta: Graha Ilmu.

Aldi, Y., \& Susanti, F. (2019). Pengaruh Stress Kerja Dan Motivasi Kerja Terhadap Prestasi Kerja Karyawan Pada PT. Frisian Flag Indonesia Wilayah Padang. https://doi.org/10.31227/osf.io/et4rn

Ari, Pangestu. Dwijayanti. 2009. Pengaruh Kecerdasan Emosional dan Kecerdasan Spiritual Dan Kecerdasan Sosial Terhadap Pemahaman Akuntansi. Skripsi. Universitas Pembangunan Nasional 'VETRAN'. Jakarta

Choiria , Anis. 2013. Pengaruh Kecerdasan Emosional, Kecerdasan Intelektual, Kecerdasan Spiritual, dan Etika Profesi Terhadap kinerja Auditor Dalam Kantor Akuntan Publik di kota Padang dan Pekanbaru.

Fabiola, Meirnawaty. 2005. Pengaruh Kecerdasan Intelektual, Kecerdasan Emosional, dan Kecerdasan Spiritual Terhadap Kinerja Karyawan di Semarang. Thesis Jurusan Akuntansi.UNDIP

Fendi, Z., \& Susanti, F. (2018). Pengaruh Kepuasan Kerja Terhadap Turnover Intention Dengan Komitmen Organisasi Sebagai Variabel Intervening Pada CV. Belibis Pariaman. https://doi.org/10.31227/osf.io/wumgx

Goleman, Daniel. 2003. Emotional Intelligence, Alih Bahasa : T. Hermay. Jakarta:GramediaPustaka. 
Junaidi, R., \& Susanti, F. (2019). Pengaruh Gaya Kepemimpinan Dan Budaya Organisasi Terhadap Kinerja Pegawai Pada UPTD Baltekkomdik Dinas Pendidikan Provinsi Sumatera Barat. https://doi.org/10.31227/osf.io/bzq75

Lisda, Afria. 2009. Pengaruh Kecerdasan Intektual, Kecerdasan Emosional Dan Kecerdasan Spiritual Terhadap prilaku etis auditor serta dampaknya bagi kinerja karyawan studi empiris pada kantor akuntan publik jakarta.

Lisda Rahmasari. Januari 2012. Pengaruh Kecerdasan Intelektual, Kecerdasan Emosional, Kecerdasan Dan Spiritual Terhadap Kinerja Karyawan. Fakultas Ekonomi Universitas AKI

Lubis, A. Y. O., \& Susanti, F. (2019). Pengaruh Gaya Kepemimpinan Dan Kompensasi Terhadap Prestasi Kerja Karyawan (Studi pada PT Japfa Comfeed Indonesia (JCI) Tbk Devisi Fam 1. https://doi.org/10.31227/osf.io/7tbrg

Mathis, R,L, dan Jackson, 2002. Human Resource Management, Alih bahasa : DianaAngelica. Jakarta : Salemba Empat

Mayliza, R. (2019). Pengaruh Gaya Kepemimpinan Dan Disiplin Kerja Terhadap Kinerja Karyawan Dengan Motivasi Kerja Sebagai Variabel Intervening Pada PT. Semen Padang. https://doi.org/10.17605/OSF.IO/FYPQ9.

Moniaga, Pingkan. 2012. Analisis Pengaruh Kecerdasan Emosional, Kecerdasan Intelektual, dan Kecerdasan Spiritual Terhadap Kinerja Karyawan (Studi Kasus Pada PT. Bank Sulut Kantor Pusat). Fakultas Ekonomi dan Bisnis Program Pasca Sarjana Magister Manajemen Universitas Sam Ratulangi Manado

NI Nyoman, Teristiyani, W,. 2014 Kecerdasan Intelektua, Kecerdasan Emosional, dan Kecerdasan Spiritual Terhadap Kinerja Dosen. Study Pada Politeknik Negri Bali. Falkutas Ekonomi Magister Manajeman.

Notoprasetio , Gunaeka, Christian. 2012 Pengaruh Kecerdasan Emosional, Kecerdasan Intelektua, Kecerdasan Dan Spiritual Terhadap Kinerja Auditor Pada Kantor Akutan Publik Di Surabaya. Jurnal Ilmiah Mahasiswa Akuntansi, Vol, No.4. juli 2012, Unika Widyamandala : Suroboyo

Ridho, M., \& Susanti, F. (2019). Pengaruh Stres Kerja Dan Motivasi Kerja Terhadap Kepuasan Kerja Pada Karyawan Bank Mandiri Syariah Cabang Padang. https://doi.org/10.31227/osf.io/pa2cg

Trihandini, R.A Vabiola Meirnawati 2005. Analisis Pengaruh Kecerdasan Intelektual, Kecerdasan Emosional, dan Kecerdasan Spiritual terhadap kinerja kKaryawan Hotel Horison Semarang . 
Yudistira, D. S., \& Susanti, F. (2019). Pengaruh Motivasi Kerja Dan Budaya Kerja Terhadap Kinerja Karyawan Dinas Pemberdayaan Masyarakat Dan Desa, Pengendalian Penduduk Dan Keluarga Berencana Kabupaten Pesisir Selatan. https://doi.org/10.31227/osf.io/jk54m 